\title{
ЛЮПИН В КОРМЛЕНИИ КУР-НЕСУШЕК РОДИТЕЛЬСКОГО СТАДА
}

\section{Е.Н. АНДРИАНОВА' ${ }^{1}$ И.А. ЕГОРОВ ${ }^{1}$, Е.Н. ГРИГОРЬЕВА' ${ }^{1}$, А.Н. ШЕВЯКОВ1, В.В. ПРОНИН ${ }^{2}$}

Климатические особенности большинства регионов России неблагоприятны для возделывания сои - неотъемлемого компонента комбикормов для сельскохозяйственной птицы. Объемы сои, производимой на российском Дальнем Востоке, в Краснодарском крае и южных областях, не могут обеспечить возрастающие потребности птицеводства в этом необходимом белковом сырье. В качестве альтернативы в кормопроизводстве стали применять отечественные низкоалкалоидные сорта белого и узколистного люпина. Кормовой люпин обычно содержит до $42 \%$ протеина. Недостатки люпина - высокое содержание клетчатки (12,5-16 \%) и лигнина (0,9 \%), а также наличие алкалоидов (в сладких сортах люпина - 0,008-0,120\%, в горьких - 1-3 \%). Возможность применения люпина вместо традиционных источников кормового белка требует изучения эффектов каждого потенциального сорта этой культуры. Нами был определен химический и аминокислотный состав зерна у российских сортов белого люпина, получены положительные результаты при включении до 15-20 \% люпина низкоалкалоидных сортов Гамма, Дега, Дикаф 14 в комбикорма для бройлеров и кур-несушек промышленного стада, а также установлено, что обогащение комбикормов, содержащих люпин, ферментными препаратами повышает продуктивность птицы за счет улучшения переваримости корма. Следует отметить, что в настоящее время в России люпин используется при выращивании цыплят-бройлеров и получении товарного яйца, однако исследований влияния этой культуры на племенную птицу в нашей стране практически нет. В представленной работе мы впервые показали возможность эффективной замены продуктов переработки сои и подсолнечника низкоалкалоидным белым люпином сорта Дега в комбикормах для курнесушек родительского стада. Установлено, что обрушение люпина позволяет не только снизить процент клетчатки в кормовых концентратах из люпина, но и обеспечивает увеличение содержания белка, которое в обрушенном люпине сопоставимо с таковым в продуктах переработки сои. В опытах на пяти группах кур-несушек кросса СП 789 (с 184- до 365-суточного возраста), которые получали сбалансированные по питательности полнорационные комбикорма с 5; 7; 10 и 15 \% обрушенного белого люпина сорта Дега, содержащего 39,61 \% протеина и 5,60 \% клетчатки (соответственно II-V группы, контроль - I группа), выявлено отсутствие его отрицательного влияния на продуктивность и сохранность птицы в изученных дозах. Замена сои люпином в комбикормах несушек III, IV и V опытных групा позволила повысить выход яиц и яичной массы в расчете на одну несушку на 1,$51 ; 7,10$ и $3,31 \%$ и 1,$64 ; 6,56$ и 3,64 \% и снизить затраты корма на 1 кг яичной массы на 0,$9 ; 4,07$ и $1,81 \%$; при этом количество неоплодотверенных яиц от несушек IV и V групп, получавших 10 и $15 \%$ люпина в рационе, было меньше, чем у контрольной птицы. В сочетании с низким отходом (категория «кровяное кольцо»), полученный результат свидетельствует об отсутствии негативного влияния 10-15\% обрушенного зерна люпина сорта Дега на развитие эмбрионов в начальный период инкубации. Мы не отмечали увеличения потерь в IV и V группах и на позднем этапе инкубации яиц, полученных от несушек в 47-недельном возрасте. Так, доля задохликов и слабых цыплят в V опытной группе, получавшей $15 \%$ люпина в рационе, составила 4 и 5 \% против соответственно 9 и 8 \% в контроле. При морфометрическом исследовании гистоструктур печени мы не выявили достоверно значимых различий между контрольной и подопытными группами, ядерно-цитоплазматическое отношение в гепатоцитах было одинаковым. Гистологические исследования показали, что печень кур во всех изучаемых группах имеет типичное строение, соединительная ткань развита слабо, встречается на периферии органа, где формирует тонкую капсулу, а также в области триад, балочное строение четко выражено, печеночные балки располагаются радиально и имеют вид ветвистой извилистой структуры. В просвете центральных вен и синусоидных капиллярах отмечается скопление форменных элементов крови. Границы гепатоцитов слабо различимы, клетки имеют полигональную форму, ядра занимают центральное положение, местами несколько оттеснены к периферии, округло-овальной формы, содержат 1-4 ядрышка. Цитоплазма зернистая, окрашена неравномерно, в строме и паренхиме органа встречаются клетки лимфоидного ряда. Результаты гистологических исследований согласуются с зоотехническими и инкубационными показателями при выращивании птицы и указывают на отсутствие цитотоксического эффекта и выраженных изменений гистоструктуры печени несушек при включении 5-15 \% люпина в рацион в качестве источника белка. Это позволяет рекомендовать белый люпин сорта Дега не только для промышленного, но и для племенного птицеводства.

Ключевые слова: белый люпин, алкалоиды, куры-несушки, продуктивность, оплодотворенность, выводимость, гистоморфология печени.

Климатические условия России не позволяют получать урожаи та- 
кой ценной культуры, как соя, в объемах, необходимых для птицеводства. В России основным белковым кормом служит подсолнечный шрот, а из зернобобовых культур - горох, кормовые бобы, вика и люпин (1-4). Высокая урожайность, культивирование в областях, где сою не выращивают или ее урожаи низкие, привлекает к люпину все больший интерес в связи с проблемой дефицита белка для кормления птицы. Созданы отечественные низкоалкалоидные сорта люпина, которые могут использоваться для замены соевых продуктов в кормопроизводстве $(5,6)$. В мировом производстве люпин занимает около 1 \% посевных площадей. В настоящее время лидеры по его выращиванию - Австралия, Новая Зеландия, Польша и Белоруссия (79). В последние годы собственные сорта низкоалкалоидного белого люпина появились в Румынии. Климатические условия Польши, Белоруссии и Германии благоприятны для возделывания узколистного и желтого люпина. Изучается его влияние на продуктивность и качество яиц птицы (10-12) при оптимизации рецептур рационов (13), эффекты антипитательных веществ (14), возможности применения низкоалкалоидных сортов (15), цельных и обрушенных семян (16). В Англии ведутся исследования по оценке кормовой ценности и перспектив использования голубого люпина $(17,18)$.

Кормовой люпин обычно содержит до 42 \% протеина и служит хорошим источником пополнения комбикормов сырым протеином, что особенно важно при дефиците качественных животных кормов и соевого шрота. К недостаткам люпина относится высокое содержание клетчатки $(12,5-16,0 \%)$ и лигнина $(0,9 \%)$, а также наличие алкалоидов (в сладких сортах люпина $-0,008-0,120 \%$, в горьких $-1-3 \%)$. Алкалоиды люпина лупинин, люпанин, люпинин, спартеин и гидроксилюпанин. Лупанин самый токсичный алкалоид, количественно преобладающий у большинства сортов горького люпина. Этот алкалоид содержит один атом азота, одну первичную спиртовую группу и может быть окислен до лупининовой кислоты. Лупинин служит основным токсическим фактором при отравлении птицы люпином, тогда как другие алкалоиды - только вспомогательные факторы при токсикозах. Минимальная токсическая доза для лупинина составляет 25-28 мг/кг, смертельная - 29-31 мг/кг живой массы (9). У российского низкоалкалоидного сорта белого люпина Дега в нативном зерне общее содержание алкалоидов составляет в среднем 0,062 \% с преобладанием люпанина $(37,1 \%)$ и дегидроксилюпанина $(14,3 \%)$, в обрушенном - повышается до 0,080 \% (3).

1. Состав алкалоидов (от абсолютно сухого вещества, \%) в зерне люпина сорта Дега (M \pm SEM) (3)

\begin{tabular}{lcc}
\hline \multicolumn{1}{c}{ Показатель } & Зерно цельное & Зерно обрушенное \\
\hline Содержание алкалоидов & $0,062 \pm 0,006$ & $0,080 \pm 0,008$ \\
Состав алкалоидов, \%: & & \\
спартеин & $5,9 \pm 0,6$ & $8,5 \pm 0,8$ \\
аммодендрин & $8,5 \pm 0,9$ & $5,4 \pm 0,5$ \\
ангустифолин & $9,5 \pm 1,0$ & $8,1 \pm 0,8$ \\
изолюпаин & $9,3 \pm 0,9$ & $8,8 \pm 0,9$ \\
афиллидин & $4,7 \pm 0,5$ & $5,7 \pm 0,6$ \\
дегидроксилюпанин & $14,3 \pm 1,4$ & $15,0 \pm 1,5$ \\
люпанин & $37,1 \pm 3,7$ & $40,1 \pm 4,0$ \\
13-оксилюпанин & $8,5 \pm 0,8$ & $6,5 \pm 0,6$ \\
эфир 13-оксилюпанин & $2,2 \pm 0,2$ & $1,4 \pm 0,1$ \\
\hline
\end{tabular}

Ранее нами $(1,2$, $19,20)$ и другими авторами (21) была изучена эффективность использования сортов Гамма и Дега при содержании бройлерах и кур-несушек промышленного стада и показана возможность вводить до $20 \%$ люпина им в рацион $(1,19)$.

Отметим, что вы-

сокое содержание клетчатки, характерное для сортов как узколистного, так и белого люпина, ограничивает применение его высоких доз в рационах сельскохозяйственной птицы. Для решения этой проблемы применяют мультиэнзимные композиции $(1,4,22)$ или обрушение бобов люпина. Последнее позволяет не только снизить количество клетчатки в кормовых 
концентратах, но повышает содержание белка, которое в обрушенном зерне люпина сопоставимо с таковым в продуктах переработки сои $(16,19)$.

Несмотря на расширение использования люпина в производственных условиях для кормления цыплят-бройлеров и кур-несушек промышленного стада, аналогичных исследований на племенной птице в нашей стране практически нет.

Мы впервые показали возможность эффективной замены низкоалкалоидным белым люпином сорта Дега продуктов переработки сои и подсолнечника в комбикормах для кур-несушек родительского стада. Установлено, что включение обрушенного зерна российского сорта белого люпина Дега в комбикорма для племенной птицы в дозе 5-15 \% не оказывает отрицательного воздействия на состояние печени несушек, ее микроморфологию и позволяет обеспечить высокую сохранность, продуктивность птицы, а также выход 1-суточного молодняка, не уступающие показателям при применении продуктов переработки сои.

Наша цель заключалась в оценке возможности применения белого люпина сорта Дега в качестве замены продуктов переработки сои и подсолнечника при кормлении кур-несушек родительского стада.

Методика. Для исследования сформировали пять групп кур-несушек кросса СП 789 (в каждой группе по 30 особей), наблюдения проводили в течение 6 мес продуктивного периода с 184-до 365-суточного возраста (виварий СГЦ «Загорское» ФНЦ «ВНИТИП» РАН, Московская обл.). Птицу содержали в клеточной батарее (ЗАО « Пятигорсксельмаш», Россия). Корм раздавали вручную. В рационы птицы вводили обрушенное тостированное зерно белого люпина сорта Дега. Условия кормления и содержания (питательность комбикормов, нормы посадки, световой, температурный и влажностный режим, фронт кормления и поения) на протяжении всего опыта соответствовали рекомендациям (Всероссийский научноисследовательский и технологический институт птицеводства, 2015). Несушки из I (контрольной) группы потребляли сбалансированные рассыпные полнорационные комбикорма без добавления люпина (основной рацион - OP). В комбикорма несушек из II, III, IV и V опытных групп включали соответственно 5; 7; 10 и 15 \% люпина, заменяя им продукты переработки сои.

В возрасте 34 и 47 нед от несушек методом искусственного осеменения получили инкубационное яйцо. Осеменение проводили по общепринятой методике с применением новой запатентованной среды для разбавления спермы петухов (патент RU № 2637774 C2), доза осеменения 0,1 мл (разбавление 1:3). По 100 яиц от каждой группы птицы помещали в экспериментальный инкубатор фирмы «Danki» (Бельгия). В течение предварительного периода инкубации (с 1-х по 18-е сут) с помощью датчика (точность до $0,1^{\circ} \mathrm{C}$ ) поддерживали температуру $37,7{ }^{\circ} \mathrm{C}$; в выводной период (с 19-х по 21-е сут) $-37,2^{\circ} \mathrm{C}$; относительная влажность соответственно $52-53 \%$ и $52-75 \%$.

Учитывали основные зоотехнические показатели - живую массу в начале и конце наблюдения (индивидуальное взвешивание), сохранность поголовья, яйценоскость; рассчитывали потребление и затраты корма на (1 гол., на 10 яиц и на 1 кг яичной массы); определяли инкубационные показатели (оплодотворенность, выводимость), содержание витаминов и каротиноидов в печени, химический состав печени, содержание кальция, фосфора и марганца в большеберцовой кости (по общепринятым методикам согласно действующим ГОСТ) (23).

По окончании опыта у кур-несушек $(n=15$, по 3 гол. из каждой 
группы) в течение 1 ч после убоя отбирали для гистологических исследований образцы печени с латеральной стороны правой доли печени. Образцы фиксировали в 10 \% водном растворе нейтрального формалина. Материал промывали в проточной воде, дегидратировали в этиловом спирте возрастающей концентрации и уплотняли парафином. Парафиновые срезы толщиной 5-8 мкм изготавливали на полуавтоматическом ротационном микротоме RMD-3000 (ООО «Креоника», Россия), депарафинированные срезы окрашивали гематоксилином и эозином. Общую морфологию изучали при помощи светового микроскопа Микромед-3 («ЛОМО», Россия), микрометрию проводили с использованием окуляр-камеры DSM 300, («Hangzhou Scopetek Opto-Electric Co.,Ltd», Китай) и программы Sco-pePhoto 3.1 (Китай) (https://scopephoto.software.informer.com/3.1/). Измеряли большой и малый диаметры гепатоцитов и их ядер, вычисляли объемы клеток, цитоплазмы и ядер, ядерно-цитоплазматическое отношение. Объем гепатоцитов и ядер определяли по формуле К. Ташкэ (24): $\pi /\left(6 \times \mathrm{L} \times \mathrm{B}^{2}\right)$, где $\mathrm{L}-$ большой диаметр клеток (ядер), мкм, В - малый диаметр клеток (ядер), мкм.

Полученные данные обрабатывали по Г.Ф. Лакину (25) и Н.А Плохинскиому (26). Использовали программу STATISTICA 10 («StatSoft, Inc.», США). Рассчитывали средние значения $(M)$ и ошибки средних ( $\pm \mathrm{SEM})$. Достоверность различий оценивали по $t$-критерию Стьюдента. Различия считали статистически значимыми при $\mathrm{p} \leq 0,05$.

Результаты. Основные показатели химического состава сорта Дега в сравнении с другими сортами белого люпина представлены в таблице 2. Безусловно, в зависимости от климатических условий содержание протеина, жира, каротиноидов может несколько различаться, но в целом представленная таблица достаточно полно отражает питательность современных сортов белого люпина отечественной селекции.

2. Химический и аминокислотный состав зерна (от абсолютно сухого вещества, \%) у российских сортов люпина

\begin{tabular}{lcc|c|c|r|r|c}
\hline \multicolumn{1}{c}{ Содержание, \% } & Старт & Мановицкий & Гамма & Дельта & Дега & Детер & Деснянский \\
\hline Влага & 9,68 & 9,44 & 8,66 & 8,45 & 8,61 & 8,65 & 8,78 \\
Протеин & 34,18 & 34,93 & 37,75 & 33,12 & 33,81 & 35,12 & 32,18 \\
Клетчатка & 10,68 & 10,92 & 10,76 & 10,21 & 10,86 & 9,95 & 10,19 \\
Жир & 9,37 & 9,28 & 9,95 & 11,25 & 9,79 & 9,90 & 11,75 \\
Зола & 3,37 & 3,09 & 3,32 & 3,12 & 3,31 & 3,11 & 3,05 \\
Кальций & 0,308 & 0,321 & 0,350 & 0,335 & 0,354 & 0,360 & 0,380 \\
Фосфор & 0,300 & 0,359 & 0,300 & 0,310 & 0,310 & 0,300 & 0,300 \\
Каротиноиды & 27,33 & 27,25 & 28,77 & 17,71 & 28,47 & 23,17 & 23,42 \\
Лизин & 1,37 & 1,41 & 1,44 & 1,43 & 1,41 & 1,57 & 1,54 \\
Гистидин & 0,79 & 0,80 & 0,94 & 0,85 & 0,81 & 0,92 & 0,94 \\
Аргинин & 2,84 & 2,91 & 3,34 & 2,99 & 2,97 & 3,17 & 2,73 \\
Аспарагиновая кислота & 3,22 & 3,16 & 3,10 & 2,96 & 2,89 & 3,35 & 3,01 \\
Треонин & 1,27 & 1,24 & 1,34 & 1,27 & 1,18 & 1,23 & 1,18 \\
Серин & 1,66 & 1,75 & 1,81 & 1,72 & 1,65 & 1,70 & 1,55 \\
Глутаминовая кислота & 6,42 & 6,95 & 7,63 & 7,28 & 7,17 & 6,78 & 6,22 \\
Пролин & 0,93 & 1,13 & 1,04 & 1,69 & 1,46 & 1,30 & 1,40 \\
Глицин & 1,17 & 1,22 & 1,28 & 1,19 & 1,18 & 1,18 & 1,12 \\
Аланин & 0,96 & 1,03 & 1,19 & 1,62 & 1,02 & 0,94 & 0,96 \\
Цистин & 0,47 & 0,39 & 0,44 & 0,48 & 0,45 & 0,45 & 0,51 \\
Валин & 1,03 & 1,06 & 1,19 & 1,09 & 1,08 & 1,08 & 1,03 \\
Метионин & 0,42 & 0,32 & 0,39 & 0,40 & 0,37 & 0,39 & 0,36 \\
Изолейцин & 1,05 & 1,13 & 1,32 & 1,17 & 1,18 & 1,21 & 1,02 \\
Лейцин & 2,01 & 2,14 & 2,44 & 2,16 & 2,22 & 2,35 & 2,18 \\
Тирозин & 1,31 & 1,40 & 1,60 & 1,36 & 1,44 & 1,55 & 1,25 \\
Фенилаланин & 1,07 & 1,11 & 1,24 & 1,28 & 1,09 & 1,20 & 1,01 \\
При меч
\end{tabular}

Пр и м е а и е. Представлены результаты анализа, выполненного в испытательном центре ФНЦ «ВНИТИП» РАН.

Результаты химического, токсикологического анализа, аминокислотный состав обрушенного зерна люпина сорта Дега приведены в таблице 3.

Установлено, что скармливание зерна белого люпина сорта Дега в 
дозе 5-15 \% в течение 6 мес продуктивного периода не снизило продуктивность и сохранность кур-несушек. Так, сохранность поголовья достигала

3. Химический состав обрушенного зерна люпина сорта Дега (в расчете на воздушно-сухое вещество)

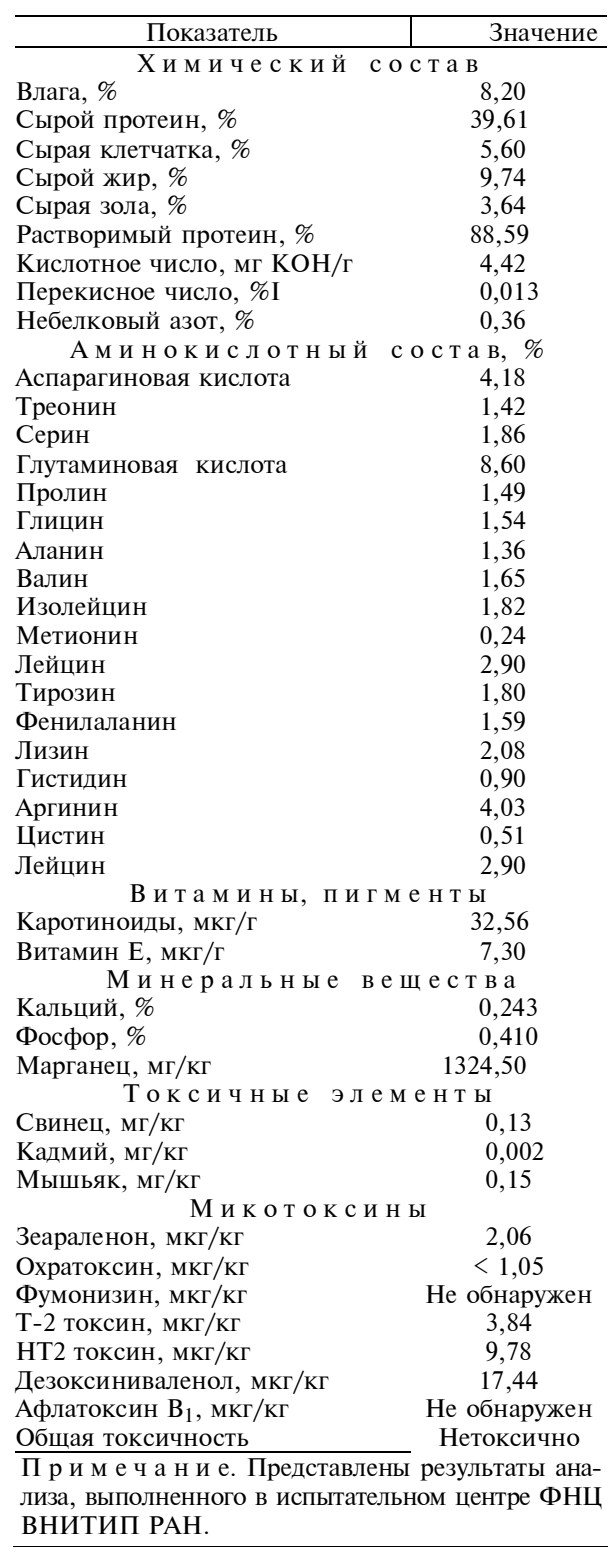

96,67-100\%. Отход птицы в контроле, а также в III и V опытных группах (соответственно 7 и $15 \%$ люпина в рационах) составил $3,33 \%$ и не был связан с кормовым фактором (табл. 4). Птица охотно потребляла комбикорма с люпином, и несмотря на более высокую продуктивность несушек в III, IV и V группах и повышенный вынос питательных веществ с яйцом, живая масса кур из этих групп в 52-недельном возрасте была на 7,25; 3,52 и 8,69\% выше, чем в контроле (различия с контролем статистически значимы при $\mathrm{p} \leq 0,5)$. При этом в расчете на 1 кг яичной массы несушки из III, IV и V групп потребили соответственно на 0,$90 ; 4,07$ и 1,81 \% меньше корма. В целом, замена люпином традиционных источников белка в комбикормах (III, IV и V группы) позволила за счет увеличения яйценоскости повысить выход яиц и яичной массы в расчете на одну несушку соответственно на 1,51 ; 7,10; 3,31\% и 1,64; 6,56; 3,64\%.

Как известно, люпин по содержанию незаменимых аминокислот уступает сое, и если нехватка лизина, метионина и треонина может компенсироваться синтетическими аминокислотами, то несбалансированность рациона по остальным аминокислотам способна приводить к снижению продуктивности несушек, в том числе за счет уменышения массы яиц. Как видно из таблицы 4, при 5-15\% люпина в рационе не отмечали существенных различий по средней массе яиц между контролем и опытными группами.

Большое значение для благополучия кур-несушек родительского стада имеет интенсивность минерального обмена, которая обеспечивает длительное поддержание хорошего состояния костяка птицы, качество скорлупы и служит залогом получения кондиционного инкубационного яйца. Величина упругой деформации, характеризующая качество скорлупы у несушек в 34-недельном возрасте в опытных группах не превышала нормативную величину (23,00 мкм). К 47-недельному возрасту этот показатель у несушек из опытных групп ухудшился (28,05-24,35 мкм против 28,77 мкм в контроле), при этом в V группе (15\% люпина в рационе) качество скорлупы было выше. Тем не менее следует отметить, что толщина скорлупы у несушек из всех групп на протяжении всего учетного периода соответ- 
4. Зоотехнические показатели у кур-несушек кросса СП 789 родительского стада за 6 мес продуктивного периода при разных дозах обрушенного зерна люпина сорта Дега в рационе $(M \pm S E M$, виварий СГЦ «Загорское ЭПХ ВНИТИП», Московская обл.)

\begin{tabular}{|c|c|c|c|c|c|}
\hline Показатель & \begin{tabular}{l|} 
I группа \\
(контроль)
\end{tabular} & \begin{tabular}{|l|} 
II группа \\
(5 \% люпина)
\end{tabular} & $\begin{array}{l}\text { III группа } \\
\text { (7 \% люпина) }\end{array}$ & $\begin{array}{l}\text { IV группа } \\
\text { (10 \% люпина) }\end{array}$ & $\begin{array}{l}\text { V группа } \\
\text { (15 \% люпина) }\end{array}$ \\
\hline Возраст птицы, сут & \multicolumn{5}{|c|}{$182-364$ сут (26-52 нед) } \\
\hline Сохранность поголовья, \% & 96,67 & 100 & 96,67 & 100 & 96,67 \\
\hline \multicolumn{6}{|l|}{ Живая масса кур, г: } \\
\hline начало опыта & $1621,67 \pm 23,54$ & $1613,67 \pm 24,43$ & $1592,73 \pm 18,19$ & $1590,87 \pm 18,02$ & $1599,87 \pm 18,02$ \\
\hline конец опыта & $1719,83 \pm 40,79$ & $1777,33 \pm 41,13$ & $1844,48 \pm 51,23^{*}$ & $1780,33 \pm 32,59^{*}$ & $1869,31 \pm 47,34^{*}$ \\
\hline \multicolumn{6}{|l|}{ Потреблено корма: } \\
\hline на 1 гол/сут, г & 114,8 & 114,78 & 114,81 & 115,68 & 115,9 \\
\hline на 10 яиц, г & 1,403 & 1,458 & 1,413 & 1,356 & 1,403 \\
\hline \multicolumn{6}{|l|}{ на 1 кг яичной } \\
\hline массы на несушку, кг & 2,21 & 2,29 & 2,19 & 2,12 & 2,17 \\
\hline Всего яиц на несушку, шт. & 144,13 & 142,50 & 146,3 & 154,37 & 148,8 \\
\hline яйценоскости, \% & 79,19 & 78,73 & 80,83 & 85,29 & 82,21 \\
\hline Средняя масса яйца, г & 64,44 & 63,75 & 64,52 & 64,11 & 64,69 \\
\hline \multicolumn{6}{|l|}{ Выход яичной массы на } \\
\hline \multicolumn{6}{|l|}{ Упругая деформация, мкм: } \\
\hline 34 нед & $24,10 \pm 1,39$ & $23,78 \pm 1,37$ & $22,90 \pm 1,34$ & $24,67 \pm 2,10$ & $22,40 \pm 0,98$ \\
\hline 47нед & $28,77 \pm 2,06$ & $28,05 \pm 1,39$ & $27,86 \pm 1,83$ & $27,97 \pm 1,61$ & $24,35 \pm 1,36$ \\
\hline \multicolumn{6}{|l|}{ Са в скорлупе в возрасте } \\
\hline кур 47 нед, \% & 37,09 & 37,29 & 37,39 & 37,60 & 37,34 \\
\hline \multicolumn{6}{|c|}{ Толщина скорлупы, мкм: } \\
\hline 34 нед & $418,50 \pm 12,15$ & $431,27 \pm 9,61$ & $409,74 \pm 6,92$ & $411,67 \pm 11,70$ & $390,28 \pm 6,10$ \\
\hline 47 нед & $378,72 \pm 8,69$ & $343,33 \pm 18,47$ & $400,66 \pm 15,29$ & $407,73 \pm 11,40$ & $394,31 \pm 8,08$ \\
\hline \multicolumn{6}{|l|}{ В большеберцовой кости } \\
\hline \multicolumn{6}{|l|}{ 364-суточных кур: } \\
\hline зола, \% & 58,00 & 57,30 & 58,62 & 60,37 & 57,75 \\
\hline $\mathrm{Ca}, \%$ & 20,30 & 20,32 & 20,80 & 21,18 & 20,29 \\
\hline $\mathrm{P}, \%$ & 9,74 & 9,50 & 9,88 & 10,05 & 9,61 \\
\hline $\mathrm{Mn}$, мг\% & 1,72 & 1,80 & 1,85 & 2,33 & 2,99 \\
\hline
\end{tabular}

Как известно, на качество скорлупы яиц влияет обеспеченность несушек кальцием, фосфором и витамином $\mathrm{D}_{3}$. Вместе с тем причиной снижения качества скорлупы и ухудшения состояния костяка также может быть недостаток или низкое усвоение птицей марганца. Мы установили, что люпин - естественный источник органических соединений марганца (27). На содержание марганца были исследованы сорта как белого, так и узколистного люпина, выращенные в разных регионах России на почвах с неодинаковым содержанием этого элемента. К примеру, в цельном зерне белого люпина сорта Гамма содержание Мn составляет 491,1 мг/кг, в зерне без оболочки - 941,63 мг/кг, в оболочке - 115,05 мг/кг (27). Повышенное накопление марганца характерно и для сорта Дега (1324,5 мг/кг в расчете на воздушно-сухое вещество). Наши результаты согласуются с данными других исследователей, по сообщению которых содержание марганца в зерне белого люпина сорта Дега $-1428,0 \pm 20$ мг/кг в расчете на абсолютно сухое вещество (3).

С увеличением дозы люпина в рационе несушек (см. табл. 4) депонирование марганца в большеберцовой кости повышалось с 1,72 мг\% в контрольной группе до 2,99 мг\% в V группt, получавшей $15 \%$ люпина в составе комбикормов. По содержанию кальция и фосфора в большеберцовой кости и скорлупе яиц достоверных различий между группами не установили. Однако анализ показал, что у кур в возрасте 47 нед при включении люпина в рацион содержание кальция в скорлупе повысилось в срав- 
нении с контролем на 0,$20 ; 0,30 ; 0,51$ и $0,25 \%$ соответственно во II, III, IV и V группах.

Как известно, полноценное развитие зародыша в первые дни инкубационного периода влияет на количественные, а главное на качественные результаты инкубации. В нашем опыте оплодотворенность яиц во всех группах была высокой и составляла 94-100 \% во все возрастные периоды (табл. 5), что обеспечивалось, в том числе, качеством разбавителя спермы петухов, который использовался для осеменения (28). Вместе с тем процент неоплодотверенных яиц от несушек из IV и V групп был меныше, чем в контроле. Этот результат в сочетании с низким отходом инкубации в категории «кровяное кольцо» свидетельствует об отсутствии негативного влияния 10-15\% обрушенного зерна люпина сорта Дега на развитие эмбрионов в начальный период. Мы не отмечали увеличение потерь в этих группах и на позднем этапе инкубации яиц, полученных от 47-недельных несушек. Так, число задохликов и слабых цыплят в V группе, получавшей 15 люпина в рационе, составило 4 и $5 \%$ против 9 и $8 \%$ в контроле.

5. Показатели (\%) биоконтроля при инкубации яиц у кур-несушек кросса СП 789 родительского стада при разных дозах обрушенного зерна люпина сорта Дега в рационе $(n=100$, виварий СГЦ «Загорское ЭПХ ВНИТИП», Московская обл.)

\begin{tabular}{|c|c|c|c|c|c|}
\hline Показатель & $\begin{array}{l}\text { I группа } \\
\text { (контроль) }\end{array}$ & $\begin{array}{l}\text { II группа } \\
\text { (5 \% люпина) }\end{array}$ & $\begin{array}{l}\text { III группа } \\
\text { (7 \% люпина) }\end{array}$ & $\begin{array}{l}\text { IV группа } \\
\text { (10 \% люпина) }\end{array}$ & $\begin{array}{l}\text { V группа } \\
\text { (15\% л люпина) }\end{array}$ \\
\hline \multicolumn{6}{|c|}{ В о з раст п т и цы 34 нед } \\
\hline Неоплод & 4 & 6 & 1 & 0 & 0 \\
\hline Кровяные кольца & 5 & 0 & 2 & 7 & 1 \\
\hline Замершие & 0 & 2 & 1 & 1 & 1 \\
\hline Задохлики & 10 & 15 & 9 & 16 & 4 \\
\hline Слабые & 2 & 5 & 8 & 7 & 2 \\
\hline Выводимость & 84,38 & 81,91 & 87,88 & 75,0 & 94,0 \\
\hline Вывод & 81 & 77 & 87 & 75 & 94 \\
\hline \multirow[t]{2}{*}{$\begin{array}{l}\text { Получено кондиционных } \\
\text { цыплят, шт. }\end{array}$} & 79 & 72 & 79 & 68 & 93 \\
\hline & & о з раст пти & ц ы 47 нед & & \\
\hline Неоплод & 6 & - & 1 & 5 & 4 \\
\hline Кровяные кольца & 2 & 1 & 0 & 1 & 3 \\
\hline Замершие & 2 & 0 & 0 & 0 & 0 \\
\hline Задохлики & 9 & 10 & 11 & 7 & 4 \\
\hline Слабые & 8 & 11 & 2 & 10 & 5 \\
\hline Выводимость & 86,17 & 89 & 88,89 & 91,58 & 92,71 \\
\hline Вывод & 81 & 89 & 88 & 87 & 89 \\
\hline Получено кондиционных & & & & & \\
\hline цыплят, шт. & 73 & 78 & 86 & 77 & 84 \\
\hline
\end{tabular}

6. Химический состав (\%) печени у кур-несушек кросса СП 789 при разных дозах обрушенного зерна люпина сорта Дега в рационе в расчете на воздушносухое вещество (виварий СГЦ «Загорское» ФНЦ ВНИТИП РАН, Московская обл.)

\begin{tabular}{|c|c|c|c|c|c|}
\hline Показатель & $\begin{array}{l}\text { I группа } \\
\text { (контроль) }\end{array}$ & $\begin{array}{l}\text { II группа } \\
\text { (5 \% люпина) }\end{array}$ & $\begin{array}{l}\text { III группа } \\
\text { (7 \% люпина) }\end{array}$ & $\begin{array}{l}\text { IV группа } \\
\text { (10 \% люпина) }\end{array}$ & $\begin{array}{l}\text { V группа } \\
\text { (15 \% люпина) }\end{array}$ \\
\hline Протеин & \multicolumn{2}{|l|}{52,34} & \multicolumn{2}{|l|}{46,20} & 48,38 \\
\hline Жир & 32,31 & 33,72 & 39,66 & 40,32 & 36,05 \\
\hline Зола & 3,88 & 3,68 & 3,90 & 3,88 & 3,95 \\
\hline \multicolumn{6}{|c|}{$\begin{array}{l}\text { П р и м е ч а н и е. Согласно использованной методике, различия считаются статистически значимыми, } \\
\text { если по содержанию протеина разница превышает } 1 \% \text {, жира }-2 \% \text {, то есть увеличение содержания жира } \\
\text { в III, IV и V опытных группах достоверное. }\end{array}$} \\
\hline
\end{tabular}

Известно, что в поздний продуктивный период снижение яйценоскости и сохранности несушек, ухудшение качества инкубационного яйца обусловлено большой частотой возникновения жировой дистрофии печени $(23,29)$. Повышенное содержание жира в печени несушек из опытных групп, потреблявших комбикорма с разным содержанием люпина (табл. 6), 
послужило основанием для проведения дополнительного гистологического анализа печени с целью установления безопасных для птицы дозировок люпина в рационе.

При морфометрическом исследовании гистоструктуры печени мы не выявили достоверно значимых различий между контрольной и остальными группами, ядерно-цитоплазматическое отношение в гепатоцитах было одинаковым (табл. 7).

7. Гистоморфометрические показатели печени у кур-несушек кросса СП 789 при разных дозах обрушенного зерна люпина сорта Дега в рационе ( $M \pm S E M$, виварий СГЦ «Загорское» ФНЦ ВНИТИП РАН, Московская обл.)

\begin{tabular}{|c|c|c|c|c|c|}
\hline Показатель & $\begin{array}{l}\text { I группа } \\
\text { (контроль) }\end{array}$ & $\begin{array}{l}\text { II группа } \\
\text { (5 \% люпина) }\end{array}$ & $\begin{array}{l}\text { III группа } \\
\text { (7 \% люпи- } \\
\text { на) }\end{array}$ & $\begin{array}{l}\text { IV группа } \\
\text { (10 \% люпи- } \\
\text { на) }\end{array}$ & $\begin{array}{l}\text { V группа } \\
\text { (15 \% люпина) }\end{array}$ \\
\hline \multicolumn{6}{|l|}{ Объем, мкм³: } \\
\hline гепатоцита & $511,73 \pm 36,04$ & $494,18 \pm 27,61$ & $383,00 \pm 24,45$ & $420,56 \pm 25,21$ & $496,00 \pm 30,59$ \\
\hline ядра & $45,07 \pm 2,41$ & $41,2 \pm 2,30$ & $38,73 \pm 2,32$ & $38,57 \pm 2,02$ & $41,66 \pm 2,48$ \\
\hline цитоплазмы & $466,66 \pm 35,31$ & $452,98 \pm 27,14$ & $344,62 \pm 23,99$ & $381,99 \pm 24,46$ & $454,32 \pm 30,10$ \\
\hline \multicolumn{6}{|l|}{ Ядерно-цитоплазма- } \\
\hline тическое отношение & $0,10 \pm 0,01$ & $0,09 \pm 0,01$ & $0,12 \pm 0,01$ & $0,11 \pm 0,01$ & $0,10 \pm 0,01$ \\
\hline Трабекулы, мкм & $18,92 \pm 0,53$ & $19,72 \pm 0,44$ & $18,43 \pm 0,40$ & $18,82 \pm 0,48$ & $18,79 \pm 0,47$ \\
\hline Синусоиды, мкм & $4,16 \pm 0,19$ & $4,63 \pm 0,20$ & $4,46 \pm 0,19$ & $4,42 \pm 0,21$ & $4,69 \pm 0,22$ \\
\hline
\end{tabular}

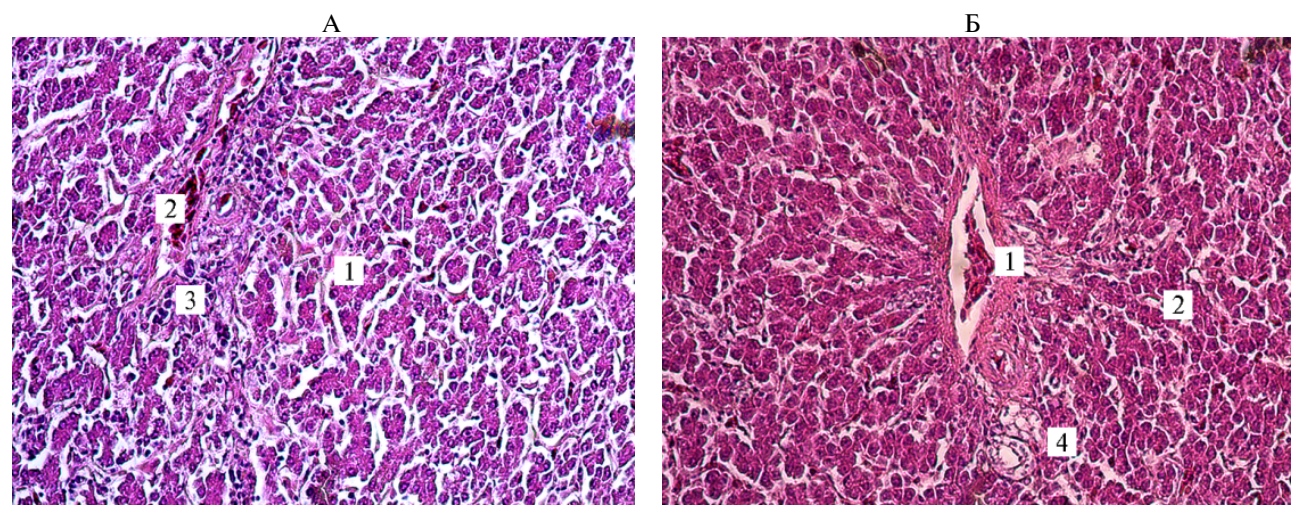

Рис. 1. Микроморфология печени у кур-несушек кросса СП 789 в возрасте 365 сут при скармливании обрушенного зерна люпина сорта Дега: А - рацион без люпина, Б - рацион с $5 \%$ люпина; 1 - гепатоциты, 2 - центральная вена с эритроцитами, 3 - лимфоциты, 4 синусоидные капилляры. Окрашивание гематоксилином и эозином; световая микроскопия (Микромед-3, «ЛОМО», Россия), увеличение ×300.

Гистологические исследования показали, что у кур во всех изучаемых группах печень имеет типичное строение, соединительная ткань развита слабо, встречается на периферии органа, где формирует тонкую капсулу, а также в области триад, балочное строение четко выражено, печеночные балки располагаются радиально, они ветвистые, извилистые. В просвете центральных вен и синусоидных капиллярах отмечается скопление форменных элементов крови. Границы гепатоцитов слабо различимы, клетки имеют полигональную форму, ядра занимают центральное положение, местами несколько оттеснены к периферии, округло-овальной формы, содержат 1-4 ядрышка. Цитоплазма зернистая, окрашена неравномерно, в строме и паренхиме органа встречаются клетки лимфоидного ряда (рис. 1, 2). Полученные нами данные о гистостроении печени кур не противоречат сведениям других авторов (30-34).

Таким образом, включение 5-15\% обрушенного зерна люпина в рацион кур-несушек родительского стада в качестве источника белка не снижало зоотехнические и инкубационные показатели. У птицы на протяжении длительного времени отмечали высокую яичную продуктивность, 


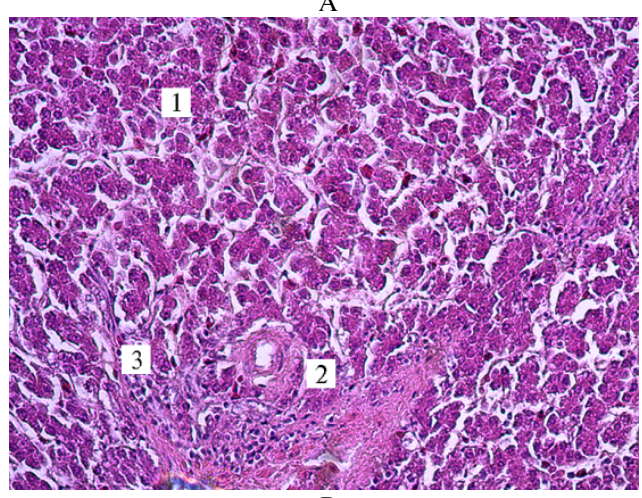

B

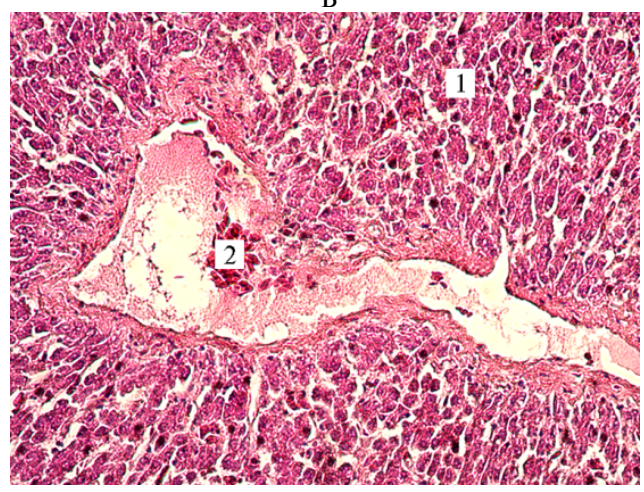

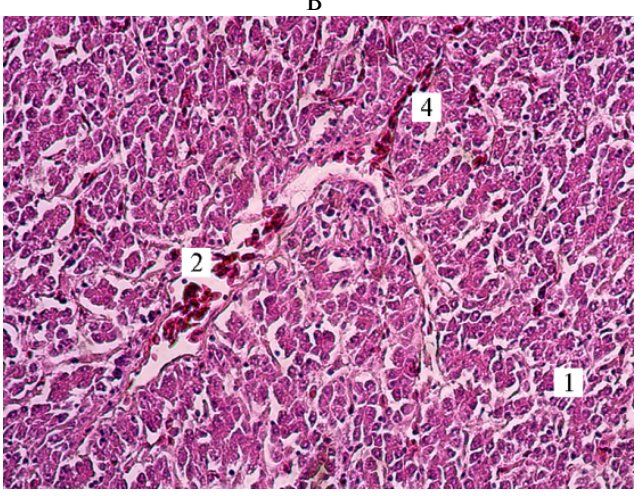

Рис. 2. Микроморфология печени у кур-несушек кросса СП 789 в возрасте 365 сут при скармливании обрушенного зерна люпина сорта Дега в дозах $7 \%$ (A), $10 \%$ (Б) и $15 \%$ (В): 1 - гепатоциты, 2 - печеночная триада, 3 - лимфоциты, 4 - синусоидные капилляры. Окрашивание гематоксилином и эозином; световая микроскопия (Микромед-3, «ЛОМО», Россия), увеличение $\times 300$.

а сохранность поголовья в опытных группах не уступала контролю даже при высоких дозах люпина в комбикорма. Результаты гистологических исследований подтверждают отсутствие выраженного цитотоксического воздействия люпина на гистоструктуру печени несушек и согласуются с их зоотехническими и инкубационными показателями. Это позволяет нам рекомендовать белый люпин сорта Дега для применения в источника кормового белка не только в промышленном, но и в племенном птицеводстве.

\footnotetext{
${ }_{1}^{1}$ ФБУ ФНЦ Всероссийский научно-исследовательский и технологический институт птицеводства,

141311 Россия, г. Сергиев-Посад, Московская обл.,

ул. Птицеградская, 10,

e-mail: andrianova@vnitip.ru $\bowtie$, olga@vnitip.ru, vnitip@vnitip.ru,

alex.shevy@mail.ru;

2ФГБУ Федеральный центр охраны здоровья животных, 600901 Россия, г. Владимир, мкр. Юрьевец, ФГБУ ВНИИЗЖ,

e-mail: proninvv63@mail.ru
}

\section{Поступила в редакцию 21 сентября 2018 года}

Sel'skokhozyaistvennaya biologiya [Agricultural Biology], 2019, V. 54, № 2, pp. 326-336

\title{
LUPINE IS APPLICABLE IN DIETS FOR LAYER CHICKENS OF PARENTAL FLOCK
}

\author{
E.N. Andrianova1, I.A. Egorov', E.N. Grigoryeva', A.N. Shevyakov', V.V. Pronin ${ }^{2}$
}

\begin{abstract}
${ }^{1}$ Federal Scientific Center All-Russian Research and Technological Poultry Institute RAS, 10, ul. Ptitsegradskaya, Sergiev Posad, Moscow Province, 141311 Russia, e-mail andrianova@vnitip.ru (corresponding author $\square$ ), olga@vnitip.ru, vnitip@vnitip.ru, alex.shevy@mail.ru;

${ }^{2}$ Federal Center for Animal Health Control, FGBU VNIIZZh, mkr. Yurievets, Vladimir, 600901 Russia, e-mail proninvv63@mail.ru
\end{abstract}

ORCID:

Andrianova E.N. orcid.org/0000-0002-6769-6351

Egorov I.A. orcid.org/0000-0001-9122-9553

The authors declare no conflict of interests

Received September 21, 2018

Shevyakov A.N. orcid.org/0000-0001-7117-1067

Pronin V.V. orcid.org/0000-0002-6240-3062

doi: 10.15389/agrobiology.2019.2.326eng 


\section{Abstract}

Climatic conditions in most Russian regions are unfavorable for the cultivation of soy beans which are considered the best protein source in diets for all types of poultry. Soya yield in Russian soya-producing regions (Far East, Krasnodar Krai, and some other southern territories) cannot provide the growing poultry production with this important protein source. The alternatives for soybean meal and other soya products are therefore in need; domestically selected low-alkaloid cultivars of white and narrow-leaf lupine are increasingly gaining importance as vegetable protein sources. Feed-grade lupine usually contains up to $42 \%$ of crude protein. The disadvantages of lupine are high contents of fiber (12.5-16.0\%) and lignin (0.9\%), and the presence of alkaloids. Alkaloid content in sweet lupine cultivars is $0.008-0.12 \%$, in bitter cultivars $1-3 \%$. Chemical and amino acid composition of white lupine modern cultivars was earlier determined, and their efficiency in poultry diets was studied in vivo. It was found that the grain of low-alkaloid cultivars Gamma, Dega, Dikaf 14 can be included into the diets for poultry at 15-20\% dosage. Supplementation of lupinecontaining diets with proper enzyme preparations can improve the digestibility of dietary nutrients and poultry performance. Dehulling of lupine grain decreases fiber content and increases protein content in concentrated lupine-based protein feeds; the latter in dehulled lupine is close to that in soybean products. This original research for the first time proves the possibility of soybean and sunflower meals substitution for white low-alkaloid lupine cultivar Dega the in diets for parental flock of laying hens. The trial was performed on 5 groups of parental White Leghorn layers (cross SP 789) from 184 to 365 days of age fed balanced diets containing $0 ; 5 ; 7 ; 10$; and $15 \%$ of dehulled Dega lupine grain $(39.61 \%$ crude protein, $5.60 \%$ crude fiber). It was found that $5-10 \%$ lupine does not impair livability and productivity parameters in layers. Lupine was found to influence the intensity of lay, egg fertility, hatch of chicks, micromorphology of liver in hens. The substitution of soy for lupine $(7,10$, and $15 \%)$ improved egg production and egg weight output per hen by 1.51 and $7.10 \%$; 3.31 and $1.64 \%$; 6.56 and $3.64 \%$, respectively, in compare to control; feed expenses per $1 \mathrm{~kg}$ egg weight in these groups was $0.9 ; 4.07$; and $1.81 \%$ lower. The percentages of infertile eggs and early embryonic deaths in using 10 and $15 \%$ lupine were lower compared to control, evidencing the absence of negative impact of lupine Dega on early embryonic development. The highest doses of lupine did not increase the incidence of late embryonic deaths in eggs from layers aged 47 weeks: the percentages of late embryonic deaths and weak chicks from layers fed $15 \%$ lupine were 4 and $5 \%$ vs. 9 and $8 \%$ in control. The histological investigation of liver revealed no significant differences between lupine-fed and control layers; nucleoplasmic ratio in the hepatocytes was similar in all treatments. In all treatments liver had no abnormalities, the connective tissues were poorly developed and located in the peripheral segments of the liver (where it forms a capsule) and near the portal triad. The hepatic plate structure is well developed, and the tortuous plates are radially oriented. The clusters of blood cells are seen in the lumen of the central veins and sinuous capillaries. Hepatocytes are not clearly bordered, polygonal in shape; nuclei centered or sometimes slightly peripherally shifted, round or oviform, has 1-4 nucleoli. Cytoplasm is unevenly stained, granular; lymphoid cells are found in the stroma and parenchyma. The results of histological investigation of liver, productivity parameters in layers, and the efficiency of incubation of eggs obtained evidence that 5-15\% of Dega lupine dehulled grain as a protein source in diets of laying hens from parental flock does not impair productivity and rendered no cytotoxic effects on the liver of hens. This cultivar of white lupine can be recommended as a dietary protein source both for commercial and parental layer flocks.

Keywords: white lupine, alkaloids, laying hens, productivity, egg fertility, hatchability, liver histomorphology.

\section{R E F E R E N C E S}

1. Egorov I., Andrianova E., Prisyazhnaya L., Shtele A. Ptitsevodstvo, 2009, 9: 25-27 (in Russ.).

2. Egorov I.A., Andrianova E.N., Tsygutkin A.S., Shtele A.L. Dostizheniya nauki $i$ tekhniki APK, 2010, 9: 36-38 (in Russ.).

3. Yagovenko T., Afonina E. Kombikorma, 2018, 3: 66-68 (in Russ.).

4. Egorov I.A., Lenkova T.N., Manukyan V.A. et al. Nastavleniya po ispol'zovaniyu netraditsionnykh kormov $v$ ratsionakh ptitsy /Pod red. V.I. Fisinina [Instructions on the use of unconventional feed in poultry diets. V.I. Fisinin (ed.)]. Sergiev Posad, 2016 (in Russ.).

5. Vashchekin E.P., D'yachenko A.P. Metabolism and semen production of sires using in the ration the ground bean of blue lupine. Sel'skokhozyaistvennaya Biologiya [Agricultural Biology], 2008, 4: 58-63 (in Russ.).

6. Shtele A.L. Belyi lyupin, 2015, 1: 15-20 (in Russ.).

7. Kubiś M., Kaczmarek S.A., Nowaczewski S., Adamski M., Hejdysz M., Rutkowski A. Influence of graded inclusion of white lupin (Lupinus albus) meal on performance, nutrient digestibility and ileal viscosity of laying hens. British Poultry Science, 2018, 59(4): 477-484 (doi: 10.1080/00071668.2018.1459041).

8. Beyene G., Ameha N., Urge M., Estifanos A. Replacing soybean meal with processed lupin (Lupinus albus) meal as poultry layers feed. Livestock Research for Rural Development, 2014, 26(11): 204. 
9. Laudadio V., Tufarelli V. Influence of substituting dietary soybean meal for dehulledmicronized lupin (Lupinus albus cv. Multitalia) on early phase laying hens production and egg quality. Livestock Science, 2011, 140(1-3): 184-188 (doi: 10.1016/j.livsci.2011.03.029).

10. Krawczyk M., Przywitowski M., Mikulski D. Effect of yellow lupine (L. luteus) on the egg yolk fatty acid profile, the physicochemical and sensory properties of eggs, and laying hen performance. Poultry Science, 2015, 94(6): 1360-1367 (doi: 10.3382/ps/pev092).

11. Park J.H., Lee S.I., Kim I.H. Effects of lupin seed supplementation on egg production performance, and qualitative egg traits in laying hens. Veterinarni Medicina, 2016, 61(12): 701-709 (doi: 10.17221/330/2014-VETMED).

12. Rutkowski A., Hejdysz M., Kaczmarek S., Adamski M., Nowaczewski S., Jamroz D. The effect of addition of yellow lupin seeds (Lupinus luteus L.) to laying hen diets on performance and egg quality parameters. Journal of Animal and Feed Sciences, 2017, 26(3): 247-256 (doi: 10.22358/jafs/76322/2017).

13. Jeroch H., Kozlowski K., Mikulski D., Jamroz D., Schoene F., Zdunczyk Z. Lupines (Lupinus spp.) as a protein feedstuff for poultry. 2. Results of poultry feeding trials and recommendations on diet formulation. European Poultry Science, 2016, 80: 166 (doi: 10.1399/eps.2016.166).

14. Jamroz D., Kubizna J. Harmful substances in legume seeds - their negative and beneficial properties. Polish Journal of Veterinary Sciences, 2008, 11: 389-404.

15. Mierlita D., Simeanu D., Pop I.M., Criste F., Pop C., Simeanu C., Lup F. Chemical composition and nutritional evaluation of the lupine seeds (Lupinus albus L.) from low-alkaloid varieties. Revista de Chemie, 2018, 69(2): 453-458.

16. Hejdysz M., Kaczmarek S.A., Kubis M., Jamroz D., Kasprowicz-Potocka M., Zaworska A., Rutkowski A. Effect of increasing levels of raw and extruded narrow-leafed lupin seeds in broiler diet on performance parameters, nutrient digestibility and $\operatorname{AME}(\mathrm{N})$ value of diet. Journal of Animal and Feed Sciences, 2018, 27(1): 55-64 (doi: 10.22358/jafs/83015/2018).

17. Lee M.R.F., Parkinson S., Fleming H.R., Theobald V.J., Leemans D.K., Burgess T. The potential of blue lupins as a protein source in the diets of laying hens. Veterinary and Animal Science, 2016, 1-2: 29-35 (doi: 10.1016/j.vas.2016.11.004).

18. Hammershøj M., Steenfeldt S. Effects of blue lupin (Lupinus angustifolius) in organic layer diets and supplementation with foraging material on egg production and some egg quality parameters. Poultry Science, 2005, 84(5): 723-733 (doi: 10.1093/ps/84.5.723).

19. Andrianova E.N. Nauchnoe obosnovanie povysheniya effektivnosti ispol'zovaniya kormov pri proizvodstve yaits $i$ myasa ptitsy. Dokt. dis. [Scientific rationale for improving the efficiency of feed use in production of poultry eggs and meat. DSci Thesis]. Sergiev Posad, 2013 (in Russ.).

20. Tsygutkin A.S., Shtele A.L., Andrianova E.N., Medvedeva N.V. Dostizheniya nauki i tekhniki APK, 2011, 9: 41-43 (in Russ.).

21. Artyukhov A.I., Yagovenko T.V., Afonina E.V., Troshina L.V. Kolichestvennoe opredelenie alkaloidov v lyupine: metodicheskie rekomendatsii [Quantitative determination of alkaloids in lupine: methodical recommendations]. Bryansk, 2012 (in Russ.).

22. Mera-Zúñiga F., Pro-Martínez A., Zamora-Natera J.F., Sosa-Montes E., Guerrero-Rodríguez J.D., Mendoza-Pedroza S.I., Cuca-García J.M., López-Romero R.M., Chan-Díaz D., Becerril-Pérez C.M., Vargas-Galicia A.J., Bautista-Ortega J. Soybean meal substitution by dehulled lupine (Lupinus angustifolius) with enzymes in broiler diets. Asian-Australasian Journal of Animal Science, 2018, 32(4): 564-573 (doi: 10.5713/ajas.18.0340).

23. Egorov I.A., Manukyan V.A., Okolelova T.M. et al. Rukovodstvo po kormleniyu sel'skokhozyaistvennoi ptitsy /Pod red. V.I. Fisinina, I.A. Egorova [Poultry feeding - a guideline. V.I. Fisinin, I.A. Egorov (eds.)]. Sergiev Posad, 2018 (in Russ.).

24. Tashke K. Vvedenie v kolichestvennuyu tsito-gistologicheskuyu morfologiyu [Introduction to quantitative cyto-histological morphology]. Rumyniya, 1980 (in Russ.).

25. Lakin G.F. Biometriya [Biometrics]. Moscow, 1990 (in Russ.).

26. Plokhinskii N.A. Rukovodstvo po biometrii dlya zootekhnikov [Guide to biometrics for livestock specialists]. Moscow, 1969 (in Russ.).

27. Andrianova E.N., Krivopishina L.V., Chvanova O.A., Tsygutkin A.S. Ptitsa $i$ ptitseprodukty, 2015, 5: 47-49 (in Russ.).

28. Konopleva A.P., Andreeva A.A., Trokholis T.N. Sbornik nauchnykh trudov VNITIP, 2012, 86: 24-35 (in Russ.).

29. Avtandilov G.G. Yabluchanskii N.I., Gubenko V.G. Sistemnaya stereometriya v izuchenii patologicheskogo protsessa [System stereometry in the study of the pathological process]. Moscow, 1981 (in Russ.).

30. Kolda J., Komarek V. Anatomia domacich ptaku. Praha, 1958: 146-154.

31. Hamodi H.M., Abed A.A., Taha A.M. Comparative anatomical, histological and histochemical study of the liver in three species of birds. Raf. J. Sci., 2013, 24(5): 12-23.

32. Hochleithner M., Hochleithner C., HarrisonL.D. Evaluating and treating the liver. Ch. 15. In: Clinical Avian Medicine, Vol. 1. Spix Publishing Inc., Palm Beach, Florida, 2006: 441-449.

33. Hoffman C.E., Kraupe P., Weiss L., Wittman J. Avian ATP citrate (pro-3s)-lyase. HoppeSeylers Z. Physiol. Chem., 1980, 361(7): 1117-1119.

34. Noyan A., Lossow W.J., Brot N., Chaikoff I.L. Pathway and form of absorption of palmitic acid in the chicken. J. Lipid Res., 1964, 5(4): 538-541. 